David G. Orr

\section{Preface: Landscapes of Conflict}

In November 1999 the University of Maryland hosted a symposium titled Commemoration, Conflict and the American Landscape: An Archaeology of Battlefield and Military Landscapes. The session brought scholars together to discuss the complex nature of the meanings, uses, and treatments of landscapes. The speakers consisted of scholars and managers who were involved in the caring of and the policy making for battlefield landscapes. All of the participants addressed issues related to the meaning of landscapes and how we selectively create a collective memory to commemorate these sites. How Americans create a collective memory about their past is necessarily related to how they treat, preserve, and interpret nationally significant sites. While preserving landscapes is important to heritage, there are many different philosophies on how to treat these sites. The symposium created a dialogue of the various perspectives about what people think is important to remember on the landscape. The original participants of the symposium included Stephen Potter, Clarence Geier, Laurie Burgess, Matthew Reeves, Mark Walker, Dwight Pitcaithley, Brooke Blades, Steven Smith, David Orr, Douglas Scott, and Edward Linenthal. The moderators included Terry Klein, Michael Hill, and Louise Akerson.

The symposium was divided into sections and addressed three subjects. The first session examined the historic landscape and studies related to the comprehension of strategic and tactical events that are considered of local, national, and international significance. Components included the identification of landscape features or artifact distributions generated during the historic event or events. The second session dealt with the memorial landscape, and the speakers considered the manner in which the original participants and site planners tried to interpret and commemorate the event or events of historic significance. Events commemorated by monuments as well as those events that are forgotten tell a contentious story about how we choose to remember a past. The third session explored the conceptual landscape. While clearly related to the memorial and modern landscape, the conceptual focus represents the philosophical foundation that provides the conscious or subconscious motivations for preserving or ignoring a particular physical site. The use and abuse of history to promote a broader mythology helps to create the conceptual landscape.

The mentioned themes often include contentious issues confronting site managers, interpreters, scholars, and the public. The contention may arise not only from differences in opinion but also from conflicts concerning the precise landscape theme encountered. The participants discussed the various ways to interpret landscapes, and they demonstrated that there are many variables that need to be considered when undertaking any plans to interpret, restore, or stabilize a landscape.

The participants addressed issues related to battlefields, sites of labor unrest, and cemeteries. Because some of the original participants were unable to contribute to this volume, the theme of the volume was expanded to landscapes of conflict. While derivative of the original symposium, it is important to recognize that landscapes of conflict not only include the historic battlefield but also other confrontations on the everyday landscape. While commemorative battlefields are often places of sizable destruction and mass death, landscapes of conflict can also be seen in everyday circumstances that may play out in neighborhoods and communities. So, while battlefields are an explicit example of the landscape of conflict, cityscapes, neighborhoods, and households are the places where people can struggle for control over interpretation of the past. Issues of race, gender, and class are often at the center of these confrontations. Therefore, in order to address these expanded issues, several other scholars were asked to participate in this volume.

In the final analysis, cultural landscapes are the most complex "manuscripts" given to us from the past. The breadth and depth of this collection of papers demonstrate this fact. Yet, landscapes exist in the present and are constantly changing, the most protean form of human legacies. Our everyday confrontation with historic landscapes 
gives us many perceptions of past time, present meaning, and future conjecture. Multiple messages and interpretations coexist in a single place. Thus, the past violence present at battlefield landscapes is often mollified by the natural serenity of the ground, its contours stripped of the grisly detritus of combat; the smells and sounds of armed confrontation gone forever. Synchronic "reconstructions" of battlefield landscapes can approach the past appearance of the ground prior to battle, but they cannot bring back the horrific episodes that once resulted in agony, pain, or death. Archaeology's great challenge is to assess and explain the shattered remnants of these violent moments in human history and tell the stories resulting from the surviving "invisible" landscape. In that sense, this volume is seminal to a more holistic analysis of violent confrontation on the everyday landscape.

The idea for the original conference occurred when David Orr (NPS), Mike Hill (superintendent of Petersburg National Battlefield), Brooke Blades (University of Maryland), Gail Brown (University of Maryland), and Paul Shackel (University of Maryland) gathered to discuss issues related to a cooperative agreement between the University of Maryland and Petersburg National Battlefield. Orr said that he thought it would be a great idea to showcase some of the work being performed at the park in the form of a conference. So Shackel submitted a proposal to the National
Park Service's Cultural Resource Training Initiative grants program, and Blades asked for funding from the National Park Service's National Battlefield Protection Program. Both groups said no. Then Shackel expanded the funding quest to other organizations and to other branches of the National Park Service. Broadening the support base allowed expanding the scope of the symposium to landscape issues that scholars and managers face every day across the country. The original symposium was an overwhelming success. Many organizations contributed to the success of the session, including the College of Behavioral and Social Sciences, University of Maryland, College Park; National Park Service, National Capital Region, Regional Archaeology Program; National Park Service, Valley Forge Cultural Resource Center; National Park Service, Archeology and Ethnography Program; URS Corporation; Archaeological Society of Maryland; and The Society for Historical Archaeology.

Blades was instrumental in the initial planning phases of the symposium, while Brown performed the logistical support and organization. Much of the success of the symposium is because of Brown's hard work, dedication, and organizational skills.

DAVID G. ORR

Valley Forge National Historical Park

P.O. Box 953

VALLEY Forge, PA 19482-0953 